\title{
Leitura
}

\section{A sabedoria na velhice}

Anita Liberalesso Nert

Diversamente do que se possa pensar, Viva bem a velhice não é um livro só para velhos; nem mais uma obra que realça as glórias ou as desgraças da velhice; nem mesmo um receituário para suplantar os problemas dessa quadra da vida, muito embora tanto a edição norte-americana como a brasileira sejam em tipos grandes, de fácil leitura. Ele destina-se, sim, a leitores de todas as idades, desde que interessados em compreender melhor e/ou preparar-se para a velhice.

Neste campo, ao que parece, a prática desmente o provérbio: "A vida não começa aos 40", a menos que se tenha a sabedoria de vivê-la. Como o "Savoir-Vivre", entre outras coisas, não emerge de uma hora para outra, sob o efeito mágico da chegada da idade, é melhor comecar a prepararse com antecedência. $O$ segredo consiste em aprender a construir um mundo que nos permita, quando velhos, viver uma vida tranqüila, digna e agradável. Algo como reescrever o último ato de uma peça de teatro, para nela podermos atuar tão magistralmente, a ponto de podermos ser aplaudidos tanto pelo "script" como pela nossa atuação. Se existe sabedoria na velhice, eis aí seu significado, diz Skinner.

Perspicácia? Ironia? Talvez, e nisso o autor confirma seu estilo, evidente em escritos anteriores. Confirma também o cerne de seu pensamento psicológico, embora num texto de natureza não técnica, e com pauta provavelmente sugerida pela co-autora, a gerontóloga M.E. Vaghan.

Anita Liberalesso Neri é professora na Faculdade de Educação da UNICAMP

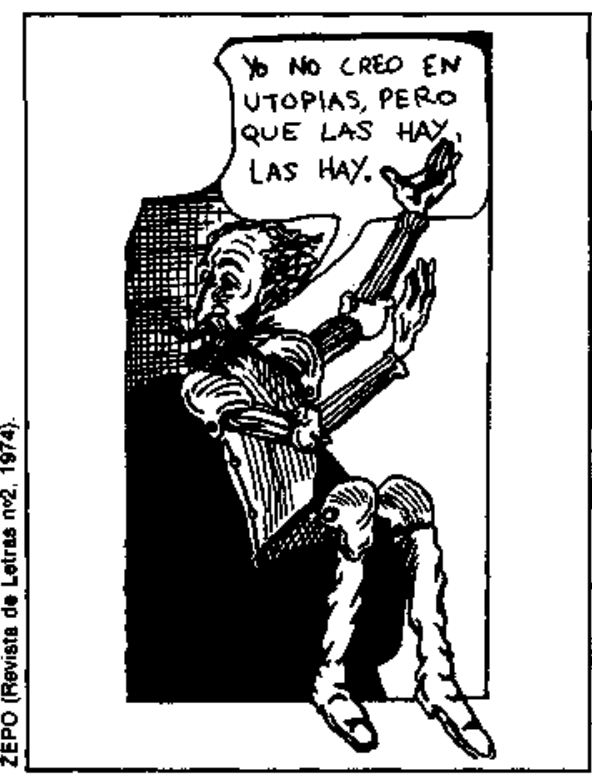

Viva bem a velhice não tem um sentido de desfrute ou fruição, mas de conquista. E um texto pequeno, bem escrito, elegante, onde o bom humor, o tom positivo, as habituais citaçōes literárias, tão características da produção skinneriana, mesclam-se num estilo saboroso e refinado. Seu sentido básico, ao que tudo indica, é o cumprimento de um objetivo ético, um projeto pessoal de Skinner, que já passou dos 80: o de revelar a seus semelhantes, o próprio segredo sobre como viver a velhice com dignidade, a despeito de suas imperfeiçōes. E assim que são tratados temas como a convivência com limitaçōes sensoriais e cognitivas, as dificuldades de relacio. namento com os mais jovens e com outros velhos, as ocupaçōes, o lidat com os sentimentos e o enfrentamen. to do medo da morte, dentre outros.

$O$ texto reflete uma realidade diferente daquela da grande maioria dos velhos brasileiros, e mesmo norteamericanos, quanto a bem-estar, saúde, habitação, dinheiro, independência, direitos, liberdade e dignidade.

Os valores, recursos e práticas veiculados, em muitos casos são distan- tes de nossa realidade, em que ninguém, nem velhos nem moços, parece cogitar dessas questões.

Nem se cogita, principalmente das ideologias e das práticas sociais que, ao vincularem trabalho, produtividade, juventude, independência e aceitabilidade social determinam não só a selvageria nas relações sociais que se vive durante o período produtivo da vida, como o insólito destino de marginalidade social reservado aos velhos.

Skinner escreve para um leitor diferenciado, talvez seus pares, e nesse sentido o livro difere de outros destinados à grande classe média norteamericana de "middle aged" ou "senior citizens", por não ser nem superficial nem prescritivo.

Em suma, o livro é interessante e com suficiente generalidade para ser aproveitado por leitores brasileiros.

Destinado a leigos, é escrito em linguagem não técnica. No entanto, não se sabe se numa manifestação de rigor ou de humor, Skinner apresenta, ao final do livro, um glossário peculiar, em que os termos e expressões de linguagem cotidiana são cotejados com seus correspondentes do discurso científico da Análise Experimental do Comportamento. Em alguns pontos a tradutora introduziu notas de rodapé contendo informações sobre a realidade brasileira.

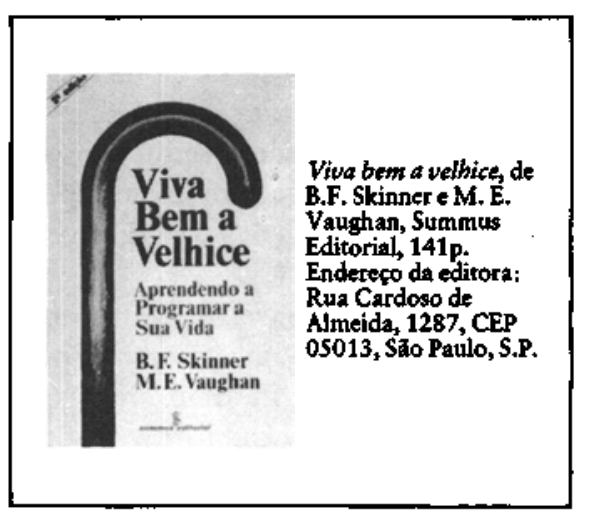

36 PSICOLOGIA, CIÉNCIA E PROFISSÃO 